Article

\title{
Decadal Climate Change in Ny-Ålesund, Svalbard, A Representative Area of the Arctic
}

\author{
Minghu Ding ${ }^{1,2}$, Shujie Wang ${ }^{1,3}$ and Weijun Sun ${ }^{3, *}$ \\ 1 Institute of Polar Meteorology, Chinese Academy of Meteorological Sciences, Beijing 100081, China; \\ dingmh@cma.gov.cn (M.D.); wangshujie1990@foxmail.com (S.W.) \\ 2 State Key Laboratory of Cryospheric Sciences, Cold and Arid Regions Environmental and Engineering \\ Research Institute, Chinese Academy of Sciences, Lanzhou 730000, China \\ 3 College of Geography and Environment, Shandong Normal University, Jinan 250014, China \\ * Correspondence: 612033@sdnu.edu.cn
}

Received: 23 February 2018; Accepted: 3 April 2018; Published: 8 April 2018

\begin{abstract}
In recent decades, global warming hiatus/slowdown has attracted considerable attention and has been strongly debated. Many studies suggested that the Arctic is undergoing rapid warming and significantly contributes to a continual global warming trend rather than a hiatus. In this study, we evaluated the climate changes of Ny-Ålesund, Svalbard, a representative location of the northern North Atlantic sector of the Arctic, based on observational records from 1975-2014. The results showed that the annual warming rate was four times higher than the global mean $\left(+0.76{ }^{\circ} \mathrm{C} \cdot\right.$ decade $\left.^{-1}\right)$ and was also much greater than Arctic average. Additionally, the warming trend of Ny-Ålesund started to slow down since 2005-2006, and our estimates showed that there is a 8-9 years-lagged, but significant, correlation between records of Ny-Ålesund and global HadCRUT4 datasets. This finding indicates that the Arctic was likely experiencing a hiatus pattern, which just appeared later than the low-mid latitudes due to transport processes of atmospheric circulations and ocean currents, heat storage effect of cryospheric components, multidecadal variability of Arctic cyclone activities, etc. This case study provides a new perspective on the global warming hiatus/slowdown debate.
\end{abstract}

Keywords: Arctic; Arctic rapid warming; global warming hiatus; global warming slowdown

\section{Introduction}

The Arctic, Antarctica, and the Tibetan Plateau are the most sensitive areas to climate change and are, therefore, considered as key components in global change estimates, including those of the WCRP (World Climate Research Program) and IGBP (International Geosphere-Biosphere Program). These areas are also of major concern in all IPCC (Intergovernmental Panel on Climate Change) reports. Compared with the attention given to Antarctica and the Tibetan Plateau, greater attention has been paid to the rapid transitions in the Arctic over the past few decades and their complex ecological and economic impacts on surrounding countries. Additionally, several international projects, including PPP (http:/ /www.polarprediction.net/) and MOSAiC (http:/ /www.mosaicobservatory.org/), have been launched to gain a better understanding of the Arctic.

The surface air temperature in the Arctic has experienced warming at a rate of more than twice the global average, a phenomenon known as Arctic amplification [1-3]. However, Arctic warming has not occurred linearly; it primarily occurred from 1920-1940 and continued from 1970 to the present, whereas pronounced cooling occurred between the two warming periods [4-6]. Many attempts have been made to interpret Arctic amplification based on the surface albedo feedback related to the decrease in snow depth, retreating sea ice extent $[7,8]$, increased meridional heat advection to the high latitudes 
resulting from atmospheric and oceanic circulations [6,9-11], and systematic changes in water vapor and cloud cover above the Arctic [12]. However, even when incorporating these processes into climate models, climate changes in polar areas remain difficult to predict, which indicates that the underlying mechanisms of polar amplification remain uncertain and debatable [13,14].

In recent years, a large number of rapid climate changes in the Arctic have greatly affected a broad spectrum of physical, ecological, and economic systems [1,15]. The volume of Arctic sea ice has decreased by 75\% since the 1980s [16,17], and the Artic will likely be nearly seasonally ice-free before 2050 [17]. The rapid reduction of Arctic sea ice plays a crucial role in the regional climate over the Arctic and even the climate and weather at lower latitudes [13]. For example, autumn-winter Arctic sea ice anomalies in 2012 affected the development of the Siberian High and resulted in extreme weather events in the winter over Eurasia [18,19]. Ten years ago, it was reported that climate change of the Arctic could be aggravated and further constrain the evolution of the global climate system in this century [20], but no authors predicted such a rapid transition as that occurring currently.

In comparison with Antarctica, the land surface of the Arctic is more complex and includes ice sheets/caps, glaciers, and frozen ground. Furthermore, climatic and environmental changes in these areas vary largely over local and regional scales and play crucial roles in feedback mechanisms [21]. Therefore, it is highly relevant to evaluate climatic changes in these regions and their similarities and differences with global average conditions. To better understand these changes, long-term and high-quality meteorological observations are key.

In this paper, climate change in $\mathrm{Ny}$-Ålesund, is evaluated using meteorological records from three stations (the Yellow River Station (YRS), Norwegian Polar Institute (NPI) and the joint French-German Arctic Research Base of the Alfred Wegener Institute for Polar and Marine Research and Polar Institute Paul Emile Victor (AWIPEV)). A further analysis and discussion are also presented to assess the related contributing factors.

\section{Study Area}

Ny-Ålesund $\left(78^{\circ} 55^{\prime} \mathrm{N}, 11^{\circ} 56^{\prime} \mathrm{E}\right)$ is located at the western coast of Svalbard, which is one of the northernmost archipelagos in the Arctic (Figure 1). The Svalbard archipelago consists of Barentsøya, Nordaustlandet, and Spitsbergen, covering a total area of $62,700 \mathrm{~km}^{2}$, and glaciers cover $60 \%$ of the surface area. The James Island ice sheet lies to the east of $\mathrm{Ny}-\mathrm{A} l e s u n d$. This area is characterized by a humid climate resulting from the North Atlantic warming current, and winter daily mean temperatures can exceed $0{ }^{\circ} \mathrm{C}$ sometime [22]. Although $\mathrm{Ny}$-Ålesund has distinct climate conditions, it can also provide evidence for climate change throughout the Arctic, especially the Atlantic sector of the Arctic, as demonstrated in the present study.

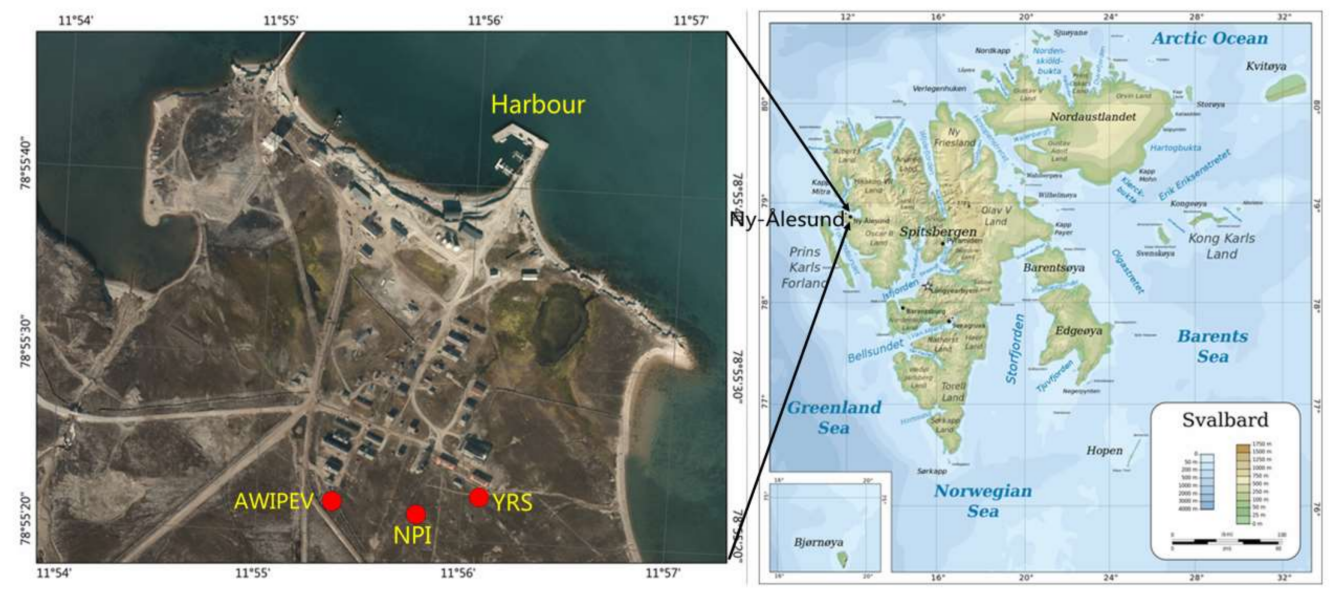

Figure 1. Aerial photo and map of Ny-Ålesund, Svalbard, Arctic. 


\section{Data Description}

The data used in this paper are derived from three automatic weather stations located at Ny-Ålesund, Svalbard (Figure 1). The Sverdrup Research Station was established by the NPI, and has daily meteorological observations from 1975 to 2014 (data available on http:/ / sharki.oslo.dnmi.no). The AWIPEV operates a $10 \mathrm{~m}$ meteorological tower locating on a field of soft tundra and provides 5-min resolution observational data from 1994 to 1998 and 1-min resolution data from 1998 to 2011 (data available on the PANGAEA repository, doi:10.1594/PANGAEA.793046). China established the YRS in 2003, and has an automated weather station located in the eastern portion of the township near the bird sanctuary. This station can provide air temperature, relative humidity, air pressure, wind speed and wind direction data, at a 1-h resolution and a height of $2 \mathrm{~m}$ from 2005 to 2014 (Table 1, data available on http:/ / www.chinare.org.cn/index/). The horizontal distances from the YRS to the AWIPEV and NPI stations are $750 \mathrm{~m}$ and $400 \mathrm{~m}$, respectively. These three stations collect observations according to WMO (World Meteorological Organization) standards with reliable sensors (Table 1 for example). To guarantee the continuity of the observational data, we used 2-m height observational data from the three meteorological stations. Note that relative humidity and wind speed data at $2 \mathrm{~m}$ were missing from January 2005 to August 2005, and wind speed data at $2 \mathrm{~m}$ of YRS were missing during 2014.

Table 1. Specifications of the automated weather Yellow River Station at Ny-Ålesund.

\begin{tabular}{|c|c|c|c|}
\hline Element & Sensor Type & Measurement Range & Accuracy \\
\hline Air temperature, ${ }^{\circ} \mathrm{C}$ & Vaisala HMP155 & $-80-60{ }^{\circ} \mathrm{C}$ & $\pm 0.2{ }^{\circ} \mathrm{C}$ \\
\hline Relative humidity, \% & Vaisala HMP155 & $0-100 \%$ & $\pm 1.7 \%$ \\
\hline Air pressure, $\mathrm{hPa}$ & Vaisala PTB220 & $500-1100 \mathrm{hPa}$ & $\pm 0.3 \mathrm{hPa}$ \\
\hline Wind speed, $\mathrm{m} \cdot \mathrm{s}^{-1}$ & XFY3-1 & $0-90 \mathrm{~m} \cdot \mathrm{s}^{-1}$ & $\pm 0.5 \mathrm{~m} \cdot \mathrm{s}^{-1}$ \\
\hline Wind direction, ${ }^{\circ}$ & XFY3-1 & $0-360^{\circ}$ & $\pm 5^{\circ}$ \\
\hline
\end{tabular}

Although the three meteorological data sets do not exactly coincide due to the different altitudes, the records of the three meteorological stations were consistent with each other, including the air temperature records, and the correlation coefficients exceeded $0.98(p<0.01)$ among the hourly records of NPI, AWIPEV, and YRS from 2006-2010.

Control criteria similar to those proposed by Maturilli et al. [22] were applied. If more than $30 \mathrm{~min}$ of data were missing within $1 \mathrm{~h}$, we considered the hourly mean value to be a missing data point. If more than $5 \mathrm{~h}$ of data were missing over one day, we considered the daily mean value to be a missing data point. If more than four days of data were missing within one month, we considered the monthly mean value to be a missing data point. Considering these durations, there were no missing monthly mean values in our datasets. Local standard time (LST, $2 \mathrm{~h}$ earlier than GMT) was used in this study.

Compared to relative humidity, specific humidity better reflects annual variations in water vapor in the atmosphere and is calculated using the following equation:

$$
q=\frac{622 e}{p-0.378 e^{\prime}}
$$

where $q$ is specific humidity, $p$ is air pressure, and $e$ is the water vapor pressure.

For convenience, we defined spring as March-May, summer as June-August, autumn as September-November, and winter as December-February. 


\section{Results}

\subsection{The Decadal Climate Change of Ny-Ålesund}

Based on the records used in this study, we found that air temperatures were relatively low from 1977 to 1983 (Figure 2a), although 1988 was the coldest year $\left(-8.5^{\circ} \mathrm{C}\right)$. In addition, the overall annual mean temperatures reflected a significant warming of $0.76 \pm 0.29^{\circ} \mathrm{C}$ decade $^{-1}$ from 1975 to 2014 ( $p<0.05)$. Furthermore, the air temperature increased in all seasons, with the largest increases occurring in winter and spring. The warming rates in spring, summer, autumn and winter were $0.58 \pm 0.5^{\circ} \mathrm{C} \cdot$ decade $^{-1}, 0.27 \pm 0.01^{\circ} \mathrm{C} \cdot$ decade $^{-1}, 0.49 \pm 0.04{ }^{\circ} \mathrm{C} \cdot$ decade $^{-1}$, and $1.17 \pm 0.07^{\circ} \mathrm{C} \cdot$ decade respectively (Figure 3). This pattern is similar to the proxy trend at Svalbard Airport reconstructed by $[23,24]$ reconstructed the air temperature in the northern Atlantic-Arctic region $\left(60^{\circ} \mathrm{W}-45^{\circ} \mathrm{E}\right.$, $60^{\circ}-90^{\circ} \mathrm{N}$ ) from 1802 to 2009 using CRUTEM3v data and four long-term observational temperature series as predictors (from Tornedalen, Iceland, Southwest Greenland, and Archangelsk). Their results exhibited a trend similar to that in Ny-Ålesund, but their estimated warming rate was much lower.

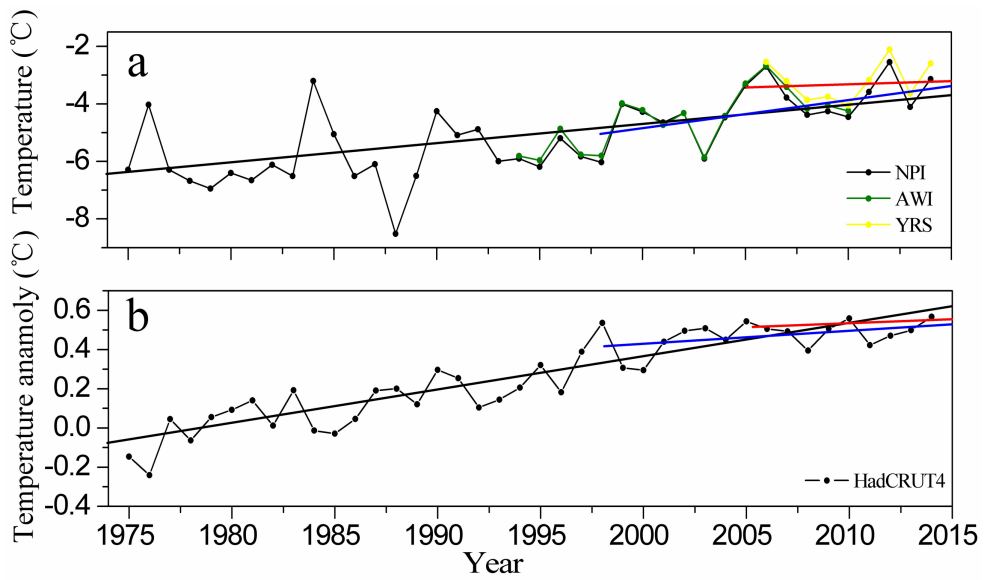

Figure 2. Comparison of the annual mean surface air temperatures at Ny-Ålesund (a) with the HadCRUT4 (b) global record. The straight black lines, blue lines, and red lines are the linearly-regressed trends.
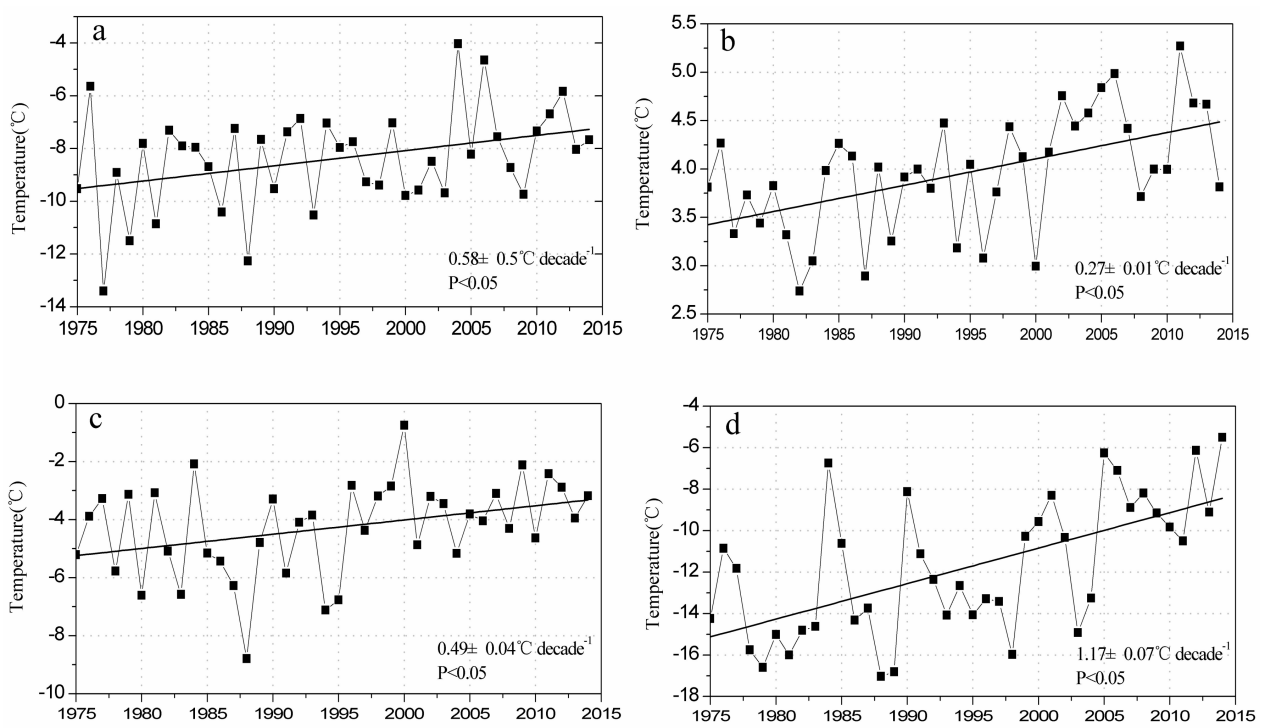

Figure 3. Inter-annual variations and linear trends in air temperature for winter (a), spring (b), summer (c), and autumn (d) at Ny-Ålesund from 1975 to 2014. 
Compared with other areas such as Svalbard Airport, Hopen, or Bjørnøya [25], Ny-Ålesund is not the warmest area. Some coastal areas in Greenland also exhibited a rapid warming during past 20 years [26]. Especially the west coast, the air temperature increased $\sim 10{ }^{\circ} \mathrm{C}$ during $1991-2012$. However, there were also some areas that exhibited cooling trends, such as the southern part of Greenland.

In recent years, the global warming hiatus/slowdown has been debated. The global warming rates during the early 2000s were lower than previous rates [27], and many studies found that the main reason should be the absence or wrong assimilation of the dataset in polar areas [28]. To evaluate whether a warming slowdown occurred in Ny-Ålesund, we compared the temperature variations in Ny-Ålesund with global variations from 1975 to 2014. Figure 2 shows that the warming rate of the annual mean temperature in $\mathrm{Ny}$-Ålesund was approximately four times greater than the global average $\left(0.76 \pm 0.29^{\circ} \mathrm{C} \cdot\right.$ decade $^{-1}$ vs. $0.17 \pm 0.03^{\circ} \mathrm{C} \cdot$ decade $\left.^{-1}, p<0.05\right)$. From $1998-2014$, the warming rate in Ny-Ålesund was $1.04 \pm 0.84{ }^{\circ} \mathrm{C} \cdot$ decade $^{-1}(p<0.05)$, whereas the global mean was $0.06 \pm 0.08^{\circ} \mathrm{C}$ decade $^{-1}(p<0.10)$, which is agreed with the pattern studied by Huang et al. [28]. In the last decade (2005-2014), the warming rate in Ny-Ålesund slowed to $0.03 \pm 1.85^{\circ} \mathrm{C} \cdot \mathrm{decade}^{-1}$ but was still higher than the global average of $0.01 \pm 0.15{ }^{\circ} \mathrm{C}$ decade $^{-1}$ (both did not pass the $95 \%$ significance test). This trend suggests that warming in Ny-Ålesund has been far greater than that of the global mean temperature and also the Arctic mean; in other words, Arctic amplification is impactful on both long- and short-term scales. From Figure 2 we can also find a warming slowdown also occurred in Ny-Ålesund, but lagged behind the decrease in the global warming rate, which will be discussed in the next part.

Similar with air temperature, specific humidity also exhibited a positive trend of $0.14 \pm 0.12$ $\mathrm{g} \cdot \mathrm{kg}^{-1} \cdot$ decade $^{-1}$ (Figure 4a) during 1994-2014, but, in summer, it was relatively stable for the strong large-scale advection of large atmospheric circulation and local evaporation effects. The air pressure differed and exhibited considerable month-to-month variations (Figure 4b), and has no significant change from 1994-2014, same with wind speed (Figure 4c).
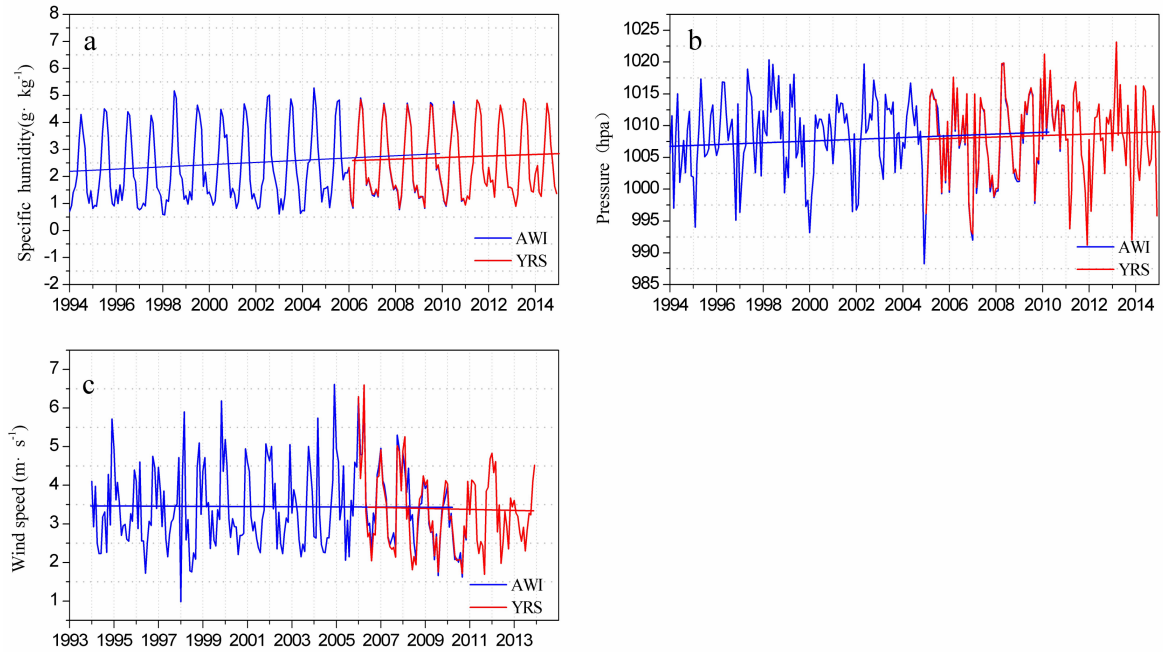

Figure 4. Variations of monthly mean specific humidity (a), air pressure (b); and wind speed (c); the blue and red straight lines represent the linear trends.

\subsection{How Long does the Climate Change of Ny-Ålesund Lag Behind the Global Change?}

Lead-lag analysis was conducted to identify the correlation between climate change of Ny-Ålesund and global mean (Figure 5). The result shows that the Ny-Ålesund and global temperature variations were remarkably consistent, with a lag time of 8-9 years. This implies that the "warming hiatus" many scientists studied also appears in Ny-Ålesund, it just started later than 
the other areas. Furthermore, it can be concluded that the Arctic can not only amplify global climate changes, but also regulates climate change by being an energy reservoir.

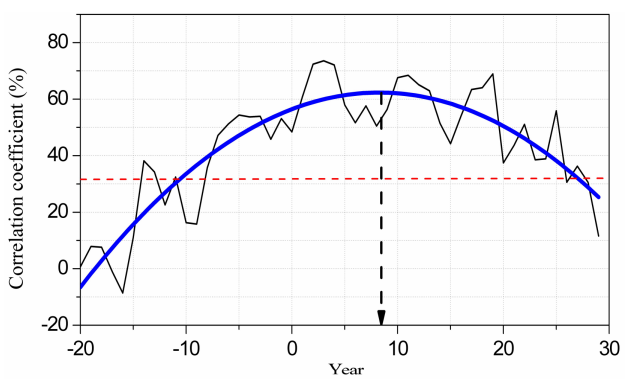

Figure 5. The lead-lag correlation analysis between the Ny-Ålesund and global air temperatures calculated using the annual mean air temperatures from NPI station and HadCRUT4 during 1975-2014. The black line represents the correlation coefficient, and the thick blue line represents a first-order polynomial fitting. The red dashed line indicates the $95 \%$ confidence level.

\subsection{Can Ny-Ålesund Represent the Arctic?}

As discussed in Section 4.1, the warming rates in Ny-Ålesund were calculated to be relatively high. However, the spatial representativeness of $\mathrm{Ny}$ - $\AA$ lesund is a key question to discuss the climate change of Arctic. To answer this question, ERA-interim reanalysis data was used for correlation analyses in the following context.

As shown in Figure 6, the correlation of air temperature, specific humidity and air pressure distributions between $\mathrm{Ny}$-Ålesund and Arctic were calculated and exhibited large scale coherence. Especially air temperature, the record of $\mathrm{Ny}$-Ålesund can capture the variation of surface temperature over most of Arctic. In one word, the observations of $\mathrm{Ny}$-Ålesund can partly represent the northern North Atlantic sector of the Arctic.

In addition, ERA-interim was able to capture the inter-annual variability in wind speed at Ny-Ålesund $(r>0.5, p<0.05)$, but there were no obvious and significantly correlated regions. This finding reveals that the wind of $\mathrm{Ny}$-Ålesund is mainly influenced by local morphology.

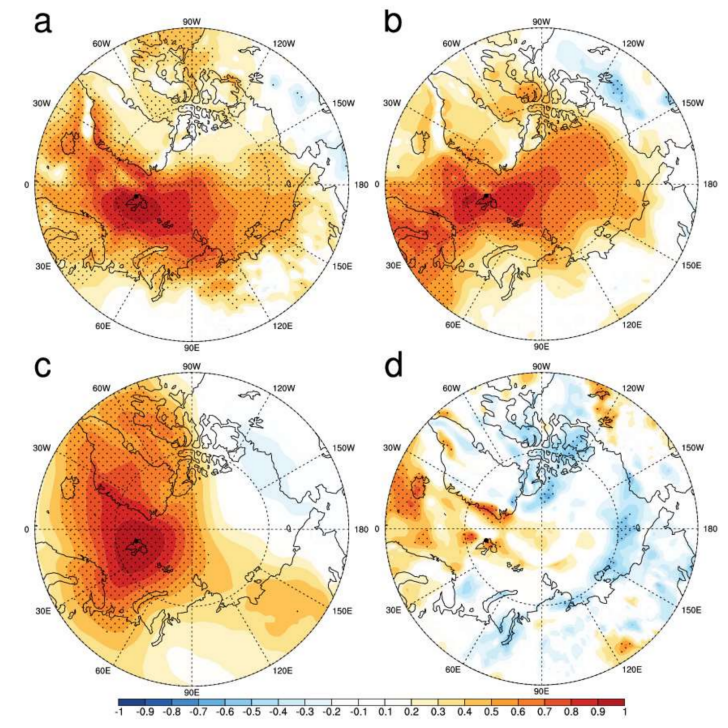

Figure 6. The spatial correlation patterns between the observed and ERA-interim modeled (a) $2 \mathrm{~m}$ temperatures, (b) specific humidity, (c) air pressures; and (d) $10 \mathrm{~m}$ winds with annual resolution during 1979-2014 for $2 \mathrm{~m}$ temperature, and 1994-2010 for specific humidity, air pressure, $10 \mathrm{~m}$ winds. The stippling indicates the $95 \%$ confidence level. 


\section{Discussion}

Compared with global climate change and Arctic climate change, Ny-Ålesund can be defined as an ART (Arctic Rapid Transition) area for its rapid warming from 1975-2014. However, the variations of air temperature lagged behind global variation sy $8-9$ years. Consequently, two questions arise: why does the climate of Ny-Ålesund change so rapidly, and why does the climate change of Ny-Ålesund lag behind global change by $8-9$ years?

\subsection{Why is the Climate of Ny-Ålesund Changes so Rapid?}

As many studies on Arctic amplification have suggested, one cause of rapid climate change in the region is sea ice retreat [13]. Since 1979, the winter sea ice area north of Svalbard has diminished by $10 \%$ decade $^{-1}$ [29]. The ice-albedo feedback mechanisms associated with the sea ice extent and changes of surface heat fluxes are responsible for Arctic amplification $[7,8,30]$. However, similar processes have also occurred in other Arctic regions; thus, this reason should not be the most important one for the rapid change.

Atmospheric cyclones can transport energy from low to high latitudes. Previous studies [31,32] have analyzed the frequencies and air pressures of cyclones that entered or formed within the Arctic basin, and found that, since the 1950s, the number of cyclones entering the Arctic basin has increased significantly (but the frequency of Arctic cyclones that formed within the Arctic basin did not). Meanwhile, the frequency of deep cyclones entered and formed within the basin also increased. These systems allow more humidity and heat to be transported to the Arctic. Furthermore, the most significant changes of seasonal parameters associated with cyclones occurred in winter [32] and have led to stronger effects on winter climate, including storms.

Although the process is slow, ocean currents can deliver more energy to polar areas due to their large heat capacities. Evidence has suggested that the northward flow of warm Atlantic water has been enhanced in recent decades [33-36] and is the major cause of heat advection that strongly affects the sea ice distribution. From observations, the surface temperature of Atlantic water has increased by $1.1{ }^{\circ} \mathrm{C}$ [29]. Ny-Ålesund locates in the Atlantic Arctic region, and is surrounded by the West Spitsbergen Current which transports advective oceanic heat from low latitudes [37]. It may play one of the most important roles in shaping local climate conditions.

A recent study [38] noted that sea ice retreat in the Barents-Kara Sea area can affect the strength and position of the polar vortex and increase the frequency of blocking regimes over the Euro-Atlantic sector in late winter. Circulation regimes in the North Atlantic may also change, which can induce local warming.

Due to sea ice retreat and more open ocean surface, there has been pronounced increase of tropospheric water vapor above the Arctic, by studies based on radiosondes, reanalysis data, or satellite retrievals [39-42]. These estimations are consistent with records of specific humidity of Ny-Ålesund. It will accelerate the warming of Arctic due to the greenhouse gas effect, whereas the stratospheric water vapor has decreased and it may cool the air of Arctic [43,44]. Additionally, these large-scale backgrounds, the frozen polar tundra domain of the land surface of Svalbard, can absorb more energy than the ocean during the polar summer due to its higher heat capacity. This seasonal regulation effect can enhance the warming during winter, and is a reason for the high climate sensitivity of Ny-Ålesund.

\subsection{Why Climate Change of Ny-Ålesund Lags Global Change by 8-9 Years?}

As we all know, most solar radiation absorbed by the Earth occurs at low latitudes, and as a consequence the global warming starts at low latitudes. The energy heating polar areas is transported by atmospheric circulations, generated by a temperature gradient between the tropics and poles.

Under the influence of global climate warming, atmospheric patterns including intensities of Arctic cyclones and Arctic sea level pressures [4,32] has changed. This may also affect the variation of air temperature. Polyakov et al. [4] studied the relation between air temperature and cyclone activity 
in the Arctic, and found that the Arctic air temperature is characterized by low-frequency oscillations, especially strong multidecadal variability, and lags behind cyclone activity by $5-15$ years. This is in agreement with our estimate.

Nevertheless, some studies found that the extent of the Siberian High has increased and moved northward since 2004, the associated meridional wind has been significantly enhanced and more warm air masses have been transported to the Arctic [45]. This will strengthen the warming of the Arctic after 2004. In addition to atmospheric circulation, large-scale sea circulation can also promote warm air and water in the Atlantic-Arctic region and influence the regional climate. Figure 7 shows the spatial patterns of correlation between annual mean air temperature of $\mathrm{Ny}$-Ålesund and the North Atlantic sea surface temperature (SST), and it can be found that the two are well correlated. This demonstrates that air masses/energy above the North Atlantic can be easily transported by cyclones or storms. However, the ocean current transfer is much slower. Warm surface currents take a long time to travel to polar areas (their interactions with surface air may accelerate the process). Controlled by trade winds and decadal changes of deeper layers over the Atlantic and Southern Oceans, the SST of the equatorial region is characterized by internal decadal variation and affects the energy distribution over the Earth's surface [46-49], whereas there is no clear mechanism for the Arctic. However, the latest results showed that the SST anomaly of the northern Nordic Seas lags behind the North Atlantic by $\sim 10$ years [50,51], and they suggested that the SST advection of Norwegian Atlantic current should be one important factor. Their findings also provide evidence for the delayed warming slowdown in Ny-Ålesund.

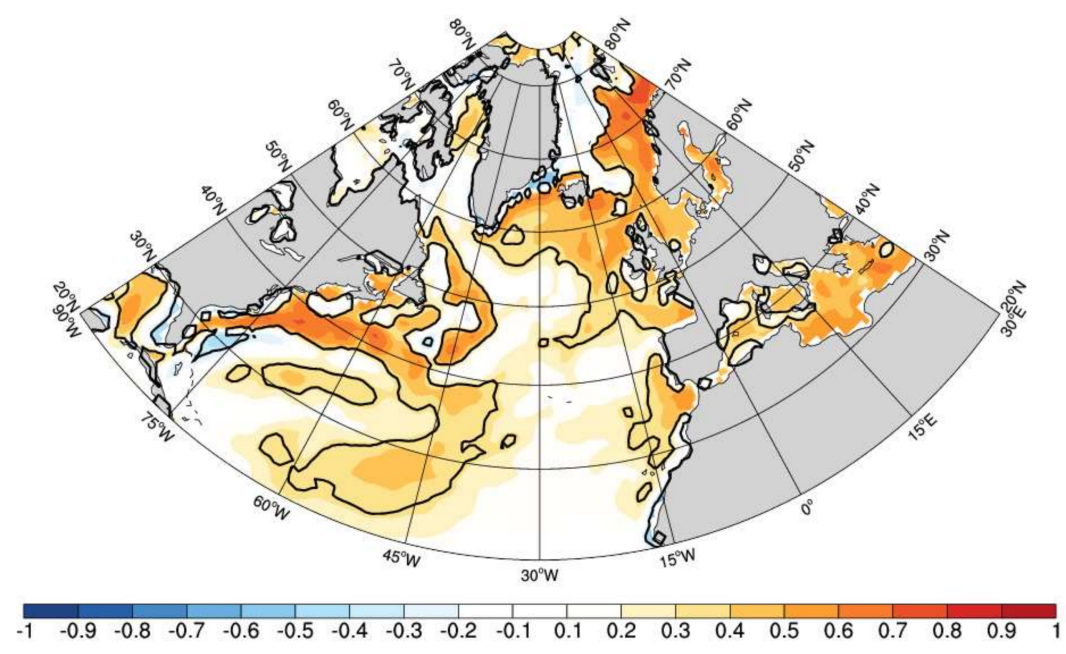

Figure 7. The spatial correlation pattern between the annual mean air temperature at Ny-Ålesund and the North Atlantic annual sea surface temperature (SST).

Sea ice, glaciers, ice sheet/caps, and frozen soil in the Arctic are sensitive components to climate change and have been retreating for years. These changes and high heat capacity can delay or slow variations in other components. In other words, energy reservoirs of these components are also key factors associated with the lagged changes in Arctic climate. However, quantifying the contributions of these factors on the decreased rate of warming is difficult, and further research is required to understand the detailed mechanisms.

\section{Conclusions}

In this paper, we estimate the variations of air temperature, specific humidity, air pressure, and wind speed during 1975-2014 in Ny-Ålesund, a typical area of frozen tundra in the Arctic. The linear trend of warming was $0.76 \pm 0.29^{\circ} \mathrm{C} \cdot \mathrm{decade}^{-1}$, four times greater than the global mean. This rapid 
warming is a comprehensive result of atmospheric activity, retreating sea ice, regional ocean-air interactions, and surface conditions, as many studies pointed out.

Although the continuous warming since the mid-1990s is inconsistent with the "hiatus", we find that there was a warming hiatus/slowdown since 2005 at Ny-Ålesund. Additionally, the variation of air temperature lags by 8-9 years, which implies that the warming hiatus probably exists in the Arctic but lags behind, globally. This phenomenon is not an isolated instance, An et al. [52] reported that the warming rate above $4000 \mathrm{~m}$ of the Tibetan Plateau has been slowing since the mid-2000s. In the Antarctic Peninsula, the slowdown of the increasing temperature trend was also found after 1998/1999, however, the reason is attributed to local phenomena, such as the deepening of Amundsen Sea Low and not due to the global hiatus [53].

From the correlation analysis, we found Ny-Ålesund could represent most Arctic areas, especially the Atlantic-Arctic sector. Therefore, this warming hiatus may also appear in other Arctic areas and convert the estimation of global change. The oscillations of atmospheric dynamic systems, the methods of energy transport from low to high latitudes, and feedback mechanisms of the Artic on climate change may contributes to the warming hiatus. However, more evidence is required and further studies need to be carried out to make this clear.

Acknowledgments: The research received financial assistance from the National Natural Science Funding of China (41771064, 41690143) and the basic funding from CAMS.

Author Contributions: W.S. provided the idea and designed the study. S.W. and M.D. illustrated the figures. M.D. wrote the manuscript.

Conflicts of Interest: The authors declare no conflict of interest.

\section{References}

1. Jeffries, M.O.; Overland, J.E.; Perovich, D.K. The arctic shifts to a new normal. Phys. Today 2013, 66, 35. [CrossRef]

2. Serreze, M.C.; Francis, J.A. The arctic amplification debate. Clim. Chang. 2006, 76, 241. [CrossRef]

3. Johannessen, O.M.; Kuzmina, S.I.; Bobylev, L.P.; Miles, M.W. Surface air temperature variability and trends in the arctic: New amplification assessment and regionalisation. Tellus 2016, 68, 28234. [CrossRef]

4. Polyakov, I.V.; Bekryaev, R.V.; Alekseev, G.V.; Bhatt, U.S.; Colony, R.L.; Johnson, M.A. Variability and trends of air temperature and pressure in the maritime arctic, 1875-2000. J. Clim. 2003, 16, 2067. [CrossRef]

5. Johannessen, O.M.; Bengtsson, L.; Miles, M.W.; Kuzmina, S.I.; Semenov, V.A.; Alekseev, G.V. Arctic climate change-Observed and modeled temperature and sea ice. Tellus 2004, 56, 328. [CrossRef]

6. Chylek, P.; Folland, C.K.; Lesins, G.; Dubey, M.K.; Wang, M. Arctic air temperature change amplification and the atlantic multidecadal oscillation. Geophys. Res. Lett. 2009, 36, 61. [CrossRef]

7. Serreze, M.C.; Barrett, A.P.; Stroeve, J.C.; Kindig, D.N. The emergence of surface-based arctic amplification. Cryosphere. Discuss. 2009, 3, 11. [CrossRef]

8. Screen, J.A.; Simmonds, I. The central role of diminishing sea ice in recent arctic temperature amplification. Nature 2010, 464, 1334. [CrossRef] [PubMed]

9. Bengtsson, L.; Semenov, V.A.; Johannessen, O.M. The early twentieth-century warming in the arctic-A possible mechanism. J. Clim. 2004, 17, 4045. [CrossRef]

10. Hwang, Y.; Frierson, D.M.W.; Kay, J.E. Coupling between arctic feedbacks and changes in poleward energy transport. Geophys. Res. Lett. 2011, 38, 752. [CrossRef]

11. Overland, J.E.; Wang, M. Large-scale atmospheric circulation changes are associated with the recent loss of arctic sea ice. Tellus 2010, 62, 1. [CrossRef]

12. Wang, X.; Key, J.R. Arctic surface, cloud, and radiation properties based on the avhrr polar pathfinder dataset. Part ii: Recent trends. J. Clim. 2005, 18, 2575. [CrossRef]

13. Pithan, F; Mauritsen, T. Arctic amplification dominated by temperature feedbacks in contemporary climate models. Nat. Geosci. 2014, 7, 181. [CrossRef]

14. Ding, Q.; Schweiger, A.; L'Heureux, M. Influence of high-latitude atmospheric circulation changes on summertime Arctic sea ice. Nat. Clim. Chang. 2017, 7. [CrossRef] 
15. Duarte, C.M.; Lenton, T.M.; Wadhams, P.; Wassmann, P. Abrupt climate change in the arctic. Nat. Clim. Chang. 2012, 2, 60. [CrossRef]

16. Schweiger, A.; Lindsay, R.; Zhang, J.; Steele, M.; Stern, H.; Kwok, R. Uncertainty in modeled arctic sea ice volume. J. Geophys. Res. Oceans 2011, 116, 128. [CrossRef]

17. Overland, J.E.; Wang, M. When will the summer arctic be nearly sea ice free? Geophys. Res. Lett. 2013, 40, 2097. [CrossRef]

18. Wu, B.; Handorf, D.; Dethloff, K.; Rinke, A.; Hu, A. Winter weather patterns over northern eurasia and arctic sea ice loss. Mon. Weather Rev. 2013, 141, 3786. [CrossRef]

19. He, J.H.; Wu, F.M.; Qi, L. Decadal/interannual linking between autumn arctic sea ice and following winter eurasian air temperature. Chin. J. Geophys. 2015, 58, 1089.

20. Mcguire, A.D.; Iii, F.S.C.; Walsh, J.E.; Wirth, C. Integrated regional changes in arctic climate feedbacks: Implications for the global climate system. Annu. Rev. Environ. Resour. 2006, 31, 61. [CrossRef]

21. Turner, J.; Overland, J.E.; Walsh, J.E. An arctic and antarctic perspective on recent climate change. Int. J. Climatol. 2007, 27, 277. [CrossRef]

22. Maturilli, M.; Herber, A.; König-Langlo, G. Climatology and time series of surface meteorology in Ny-Ålesund, Svalbard. Earth. Syst. Sci. Data 2012, 5, 1057. [CrossRef]

23. Nordli, Ø.; Przybylak, R.; Ogilvie, A.E.J.; Isaksen, K. Long-term temperature trends and variability on spitsbergen: The extended svalbard airport temperature series, 1898-2012. Polar Res. 2014, 33, 91. [CrossRef]

24. Wood, K.R.; Overland, J.E.; Jónsson, T.; Smoliak, B.V. Air temperature variations on the atlantic-arctic boundary since 1802. Geophys. Res. Lett. 2010, 37, 204. [CrossRef]

25. Rland, E.J.F.; Benestad, R.; Hanssenbauer, I.; Haugen, J.E.; Skaugen, T.E. Temperature and precipitation development at svalbard 1900-2100. Adv. Meteorol. 2011, 2011, 13.

26. Hanna, E.; Mernild, S.H.; Cappelen, J.; Steffen, K. Recent warming in greenland in a long-term instrumental (1881-2012) climatic context: I. evaluation of surface air temperature records. Environ. Res. Lett. 2012, 7, 189. [CrossRef]

27. Fyfe, J.C.; Meehl, G.A.; England, M.H.; Mann, M.E.; Santer, B.D.; Flato, G.M. Making sense of the early-2000s warming slowdown. Nat. Clim. Chang. 2016, 6, 224. [CrossRef]

28. Huang, J.; Zhang, X.; Zhang, Q. Recently amplified arctic warming has contributed to a continual global warming trend. Nat. Clim. Chang. 2017. [CrossRef]

29. Onarheim, I.H.; Smedsrud, L.H.; Ingvaldsen, R.B.; Nilsen, F. Loss of sea ice during winter north of svalbard. Tellus 2014, 66, 70. [CrossRef]

30. Overland, J.E. Future arctic climate changes: Adaptation and mitigation time scales. Earths Future 2014, 2, 68. [CrossRef]

31. Zhang, X.; Walsh, J.E.; Zhang, J.; Bhatt, U.S.; Ikeda, M. Climatology and interannual variability of arctic cyclone activity: 1948-2002. J. Clim. 2004, 17, 2300. [CrossRef]

32. Sepp, M.; Jaagus, J. Changes in the activity and tracks of arctic cyclones. Clim. Chang. 2011, 105, 577. [CrossRef]

33. Schauer, U.; Fahrbach, E.; Osterhus, S.; Rohardt, G. Arctic warming through the fram strait: Oceanic heat transport from 3 years of measurements. J. Geophys. Res. 2004, 109, 259. [CrossRef]

34. Polyakov, I.V.; Alekseev, G.V.; Timokhov, L.A.; Bhatt, U.S.; Colony, R.L.; Simmons, H.L. Variability of the intermediate Atlantic water of the arctic ocean over the last 100 years. J. Clim. 2010, 17, 4485. [CrossRef]

35. Spielhagen, R.F.; Werner, K.; Sørensen, S.A.; Zamelczyk, K.; Kandiano, E.; Budeus, G. Enhanced modern heat transfer to the arctic by warm Atlantic water. Science 2011, 331, 450. [CrossRef] [PubMed]

36. Sato, K.; Inoue, J.; Watanabe, M. Influence of the Gulf Stream on the Barents Sea ice retreat and Eurasian coldness during early winter. Environ. Res. Lett. 2014, 9, 084009. [CrossRef]

37. Walczowski, W.; Piechura, J. Influence of the west Spitsbergen current on the local climate. Int. J. Climatol. 2011, 31, 1088. [CrossRef]

38. Ruggieri, P.; Buizza, R.; Visconti, G. On the link between Barents-Kara sea-ice variability and European blocking. J. Geophys. Res. Atmos. 2016, 121, 5664. [CrossRef]

39. Francis, J.A.; Hunter, E. Changes in the fabric of the arctic's greenhouse blanket. Environ. Res. Lett. 2007, 2, 045011. [CrossRef]

40. Rinke, A.; Melsheimer, C.; Dethloff, K.; Heygster, G. Arctic total water vapor: Comparison of regional climate simulations with observations, and simulated decadal trends. J. Hydrometeorol. 2009, 10, 113. [CrossRef] 
41. Serreze, M.C.; Barrett, A.P.; Stroeve, J. Recent changes in tropospheric water vapor over the arctic as assessed from radiosondes and atmospheric reanalyses. J. Geophys. Res. 2012, 117, 10104. [CrossRef]

42. Maturilli, M.; Kayser, M. Arctic warming, moisture increase and circulation changes observed in the Ny-Ålesund homogenized radiosonde record. Theor. Appl. Climatol. 2016, 130, 1. [CrossRef]

43. Solomon, S.; Rosenlof, K.H.; Portmann, R.W.; Daniel, J.S.; Davis, S.M.; Sanford, T.J. Contributions of stratospheric water vapor to decadal changes in the rate of global warming. Science 2010, 327, 1219. [CrossRef] [PubMed]

44. Solomon, S.; Daniel, J.S.; Rd, N.R.; Vernier, J.P.; Dutton, E.G.; Thomason, L.W. The persistently variable "background" stratospheric aerosol layer and global climate change. Science 2011, 333, 866. [CrossRef] [PubMed]

45. Feng, C.; Wu, B.Y. Enhancement of Winter Arctic Warming by the Siberian High over the Past decade. Atmos. Ocean. Sci. Lett. 2015, 8, 257.

46. Kosaka, Y.; Xie, S.P. Recent global-warming hiatus tied to equatorial pacific surface cooling. Nature 2013, 501, 403. [CrossRef] [PubMed]

47. Meehl, G.A.; Arblaster, J.M.; Fasullo, J.T.; Hu, A.; Trenberth, K.E. Model-based evidence of deep-ocean heat uptake during surface-temperature hiatus periods. Nat. Clim. Chang. 2011, 1, 360. [CrossRef]

48. England, M.H.; Mcgregor, S.; Spence, P.; Meehl, G.A.; Timmermann, A.; Cai, W. Recent intensification of wind-driven circulation in the pacific and the ongoing warming hiatus. Nat. Clim. Chang. 2014, 4, 222. [CrossRef]

49. Chen, X.; Tung, K.K. Climate varying planetary heat sink led to global-warming slowdown and acceleration. Science 2014, 345, 897. [CrossRef] [PubMed]

50. Langehaug, H.R.; Matei, D.; Eldevik, T.; Lohmann, K.; Gao, Y. On model differences and skill in predicting sea surface temperature in the Nordic and Barents seas. Clim. Dyn. 2017, 48, 913. [CrossRef]

51. Årthun, M.; Eldevik, T. On anomalous ocean heat transport toward the arctic and associated climate predictability. J. Clim. 2015, 29, 151111130840000. [CrossRef]

52. An, W.; Hou, S.; Hu, Y.; Wu, S. Delayed warming hiatus over the Tibetan plateau. Earth Space Sci. 2017, 4, 128. [CrossRef]

53. Turner, J.; Ju, H.; White, I.; King, J.C.; Phillips, T.; Hosking, S.; Bracegirdle, T.; Marshall, G.J.; Mulvaney, R.; Deb, P. Absence of 21st century warming on Antarctic Peninsula consistent with natural variability. Nature 2016, 535, 411. [CrossRef] [PubMed] 